\title{
Energy saving technologies for urban bus transport
}

\author{
A. Hnatov ${ }^{1}$, Shch. Arhun ${ }^{1 *}$ and S. Ponikarovska ${ }^{2}$ \\ ${ }^{1}$ Automobile Faculty, Kharkiv National Automobile and Highway University, \\ 61002 Kharkiv, Ukraine \\ "Email: shasyana@gmail.com \\ Phone: + 380577003866; Fax: + 380577003865 \\ ${ }^{2}$ Mechanical Faculty, Kharkiv National Automobile and Highway University, \\ 61002 Kharkiv, Ukraine
}

\begin{abstract}
Reduction of non-renewable sources of energy and the ecological state of metropolises have become the cause of the search for optimal solutions for introduction of energyefficient and environmentally friendly technologies for urban bus transport, which is the purpose of this work. A review of environmentally friendly buses has shown that electric buses (electrobuses) are the most perspective. However, rapid replacement of all the buses with electrobuses is impossible because of their high cost. A comparative analysis of the operating costs of different types of buses of the same destination and class has been carried out in order to choose the optimal variant. Thus, one route of $4.23 \mathrm{~km}$ in length was chosen in Kharkiv (Ukraine). Experimental and calculated data showed that a minibus converted into an electrobus is the most acceptable means for urban passenger transportation. Ultra-capacitors are suggested as an energy source. The conceptual diagram of the model of such a bus is presented and the technical requirements for its components are determined. The data and proposals are useful for Ukraine and for countries with low economic development that cannot quickly replace old diesel buses with new, environmentally friendly, electrobuses. The results of this work are the basis for further research and development.
\end{abstract}

Keywords: Electrobus, hybrid bus, super capacitor, electric motor, battery, energyefficient technologies

\section{INTRODUCTION}

Modern society has faced a paradox: technological progress, automation, and robotisation and improvement of technological processes in all spheres of people's lives have caused huge environmental problems and depletion of natural resources. This problem is especially acute in big cities polluted with emissions of thousands of cars and buses with internal-combustion engines (ICE) which are forced to take emergency measures on reducing the factors causing environmental pollution. The solution of this problem include

i) stipulation of introduction of quality new means of its diagnosis, maintenance and repair. It should be noted that recently a great number of new energy-saving methods and ways of production, repair and maintenance of transport have appeared. For example, magnetic-pulse technologies, where non-contact metal treatment takes place the aid of excited pulsed magnetic fields. This allows 
making an external non-contact straightening of car bodies without disassembling the car and damaging the paintwork [1,2] or portable quality-confirmation inspection device for automotive body parts offered by Momang and Mohamed [3]. It makes possible to accomplish the maintenance of motor transport quickly, efficiently and, which is important, without the environmental pollution.

ii) replacement of public transport, namely, buses with modern transport by using sustainable alternative kinds of fuel. As it is known, in addition to continuous growth and development of transport facilities and its maintenance methods, there has been a constant tightening of environmental standards in transport. This issue is particularly critical in big cities, and therefore, great is paid to public transport [4-7]. In other words, it must not only possess the necessary level of comfort, but also meet all the latest environmental standards and requirements.

However, replacement of old urban buses with new ones is a challenge that mostly depends on both the budget of the country and particular organisations specialising in bus transportation. Rich and economically developed countries such as the USA, China, Norway, England, and others can afford purchasing new environmentally friendly buses, utilising and selling them to the poor countries. However, one should understand that in the countries with low economic level, let alone Ukraine which is fighting at war, the replacement of the existing buses with ICEs with the new ones is impossible. In Kharkiv alone there are over a thousand of buses carrying hundreds of thousands people daily.

One of the most promising types of modern ecologically clean type of public transport is electrobus on fuel cells [8-10]. For example, Citaro buses on hydrogen fuel cells have been tested since 2001 by the Clean Urban Transport for Europe program in various European cities [11, 12]. The advantage of these buses is that the only by-product of their work is water vapour (water). However, it should be noted that buses on fuel cells are a technologically sophisticated type of equipment. Its fuel is hydrogen, which, is the most common element on Earth, does not exist in its pure form (only in chemical compounds) and the processes of its extraction and storage are quite energy-intensive [13, 14]. The most modern and popular typeof urban public transport at the moment is hybrid buses and electrobuses, which actually reflected in the sources [15-17]. Along with the growth in the number of the appropriate infrastructure needs to be developed, it can provide a reliable and effective functioning of this type of transport. At the moment it is obvious that to do without building a broad urban and suburban network of charging stations for electrobuses and hybrid buses as well as for electric cars and plug-in hybrid cars is impossible which is reflected in the research papers [18-21]. The charging stations must be equipped in accordance with the environmental safety standards, and renewable and alternative energy sources (solar panels, wind turbines, etc.) must be used at the fullest degree as it is demonstrated in the sources [22-26]. That is why making research in the field of energy-saving technologies for urban bus transport with analysis of its main components is the key stage to choose the most optimal, in terms of ecology and economy, means of improving transport infrastructure. The purpose of the work is the search for optimal decisions for introducing energy-saving and environmentally friendly technologies for urban bus transport in the countries with low level of economic development. In order to achieve the given objective the following tasks should be solved to make the analysis of energy-saving technologies used in motor transport area, make an analysis of existing types of buses which use alternative fuels considering their advantages and disadvantages, conduct analytical and experimental research of cost effectiveness of different buses, offer the optimal model and means of modernisation of urban transport. 


\section{METHODS AND MATERIALS}

\section{Energy-saving Technologies in Transport}

The area "Energy-saving technologies in transport", in general, can be divided into two compound groups namely, infrastructure and transport (Figure 1) [27]. Consequently, infrastructure is divided into the following elements: service stations, filling stations, and energy-efficient technologies. Traditionally, road transport can be divided into buses, lorries, and cars.

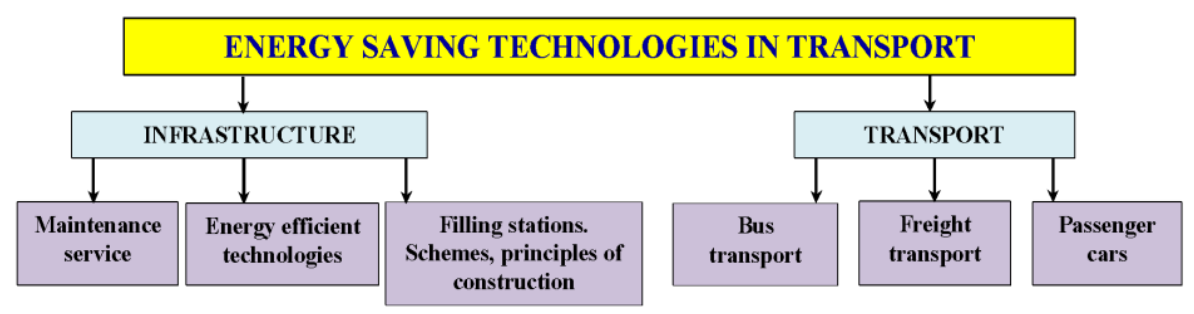

Figure 1. Energy-saving technologies in transport [27].

The "Infrastructure" group is directly dependent on the "Transport" group. It is determined by the fact that the particular type of transport needs its own infrastructure (The expression: It is a complex of interconnected, service structures or objects, composing and/or providing the basis for the system operation). For example, for road transport running on hydrogen fuel, it is necessary to develop an infrastructure that will ensure replenishment of hydrogen reserves. At the same time, for some modern types of road transport, the infrastructure can be presented by one and the same complex system, for example, a combined one for plug-in hybrid cars and electric cars [28]. Based on this, the plug-in hybrids and electric vehicles are more universal and therefore, more promising kind of modern ecological kind of transport. That is why among the energy-efficient vehicles, the hybrid and electric cars are the most widespread.

\section{An Electrobus and a Hybrid Bus}

Bus is one of the fastest growing kinds of transport in the field of energy efficient technologies. The reasons for this are the introduction of more stringent environmental standards, as well as the desire of both private enterprises and state organisations to reduce operating costs. Therefore, hybrid technologies (the combination of an internal combustion engine (ICE) with an electric motor) and electrical technologies have been applied not only in passenger cars but also in buses. Hybrid buses let maximally reduce fuel consumption, which results in minimum emissions released to the atmosphere $[5,25$, 29-32]. Thus, hybrid power-unit saves up to $60 \%$ of energy in comparison with traditional diesel units (herewith consumption of fuel decreases to $30 \%$ ), let alone the reduction of polluting emissions to the atmosphere by $70 \%$. There are several types of hybrid bus designs. One of them is shown in Figure 2. To date, hybrid vehicles have one significant advantage as compared to electric vehicles - greater autonomy of motion due to the presence of an internal combustion engine. This is due to the fact that the time of refuelling with gasoline or diesel fuel is several times less than the charging time of the batteries, besides, the network of electric stations is not sufficiently developed (especially in countries with not very high level of economic development), and the capacity of the battery (storage battery), to date is insufficient for making trips over long distances. 
However, in other respects, electric transport occupies the leading position. It is, especially true concerning electrobuses used for short routes within the city limits. So far, being environmentally responsible is not only a trend but also a necessity. The successful use of electrobuses for transportation in the city in developed countries is a proof for this $[33,34]$.

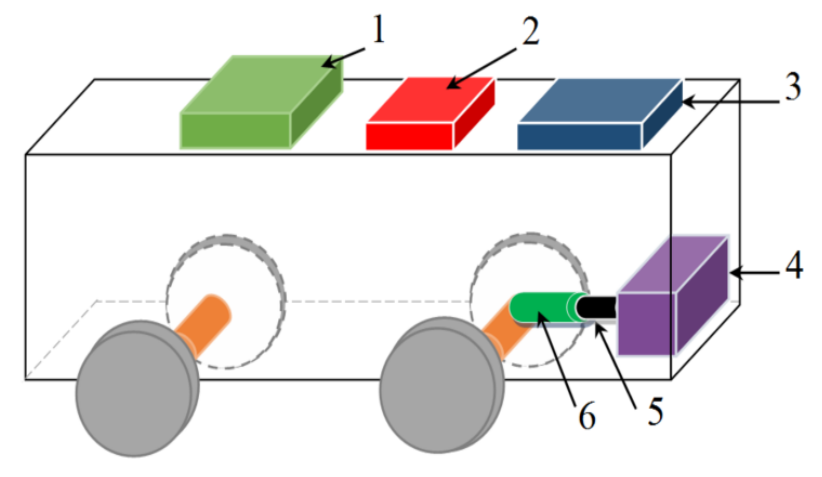

Figure 2. A hybrid bus design (1) Battery parks, (2) Control /power system, (3) Cooling system, (4) Diesel engine, (5) Electric generator, (6) Electric motor

Figure 3 shows the outer appearance of the electrobus and one of its possible designs. The biggest representative of electrobuses is BYD Auto company with a model K9 (China), Figure 3(a). These electrobuses are able to overcome the distance of $250 \ldots 300 \mathrm{~km}$ in the city without recharging. The time of their charging in special terminals is 3 hours [33]. ABB company in Luxemburg has launched rapid charge automatic systems with automatic linking-up on the roof, which can clear away one of the main obstacles for the expansion of city electrobuses use - a long time of charge with short rolling distances (Figure 4) [35]. The time of an ordinary bus charging is 4-6 minutes. The system can be easily integrated into the existing bus lines with the installation of quick charges on the route terminals, stops, depots, and (or) intermediate stops.

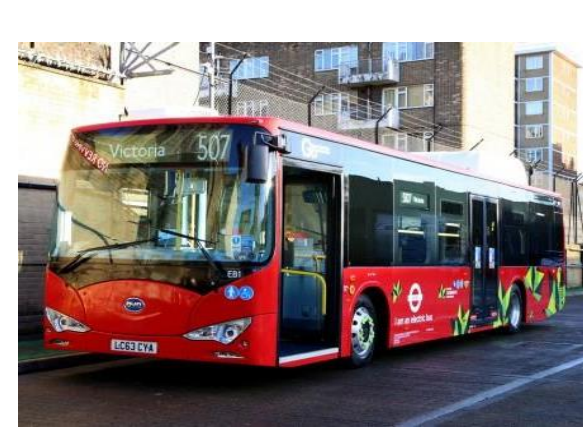

(a)

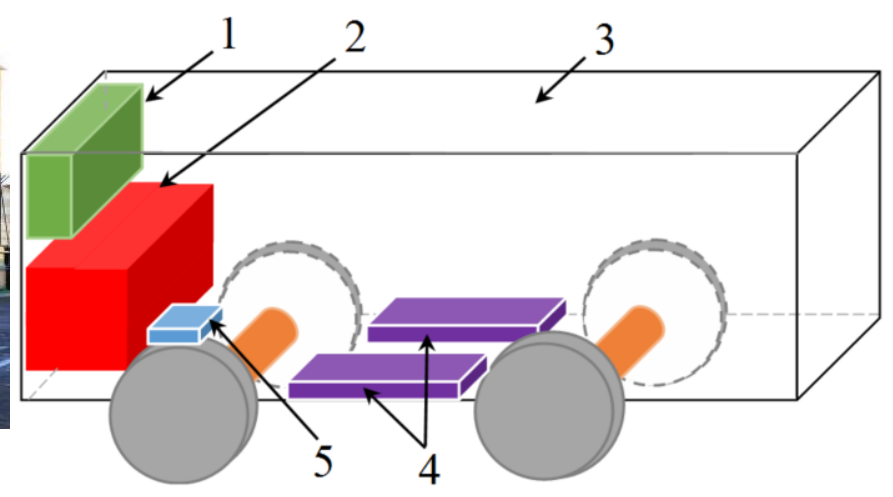

(b)

Figure 3. Electrobus (a) outer appearance of BYD K9, (b) electrobus design, (1) control panel, (2) recharging system, (3) aluminum body, (4) battary packs, (5) AC electric motor.

Existing developments of electrobuses make re-equipment of transport infrastructure possible in accordance with modern requirements in the field of 
environmental safety and at the same time avoiding the problem of insufficient battery capacity. However, despite this, a serious problem of the high cost of such buses remains, as well as the complexity and high cost of equipment for their fast charge. Of course, you can increase the capacity of batteries by adding their number but this will enlarge their weight and dimensional characteristics. Therefore, the problem of energy-intensive batteries for electric transport is also relevant.

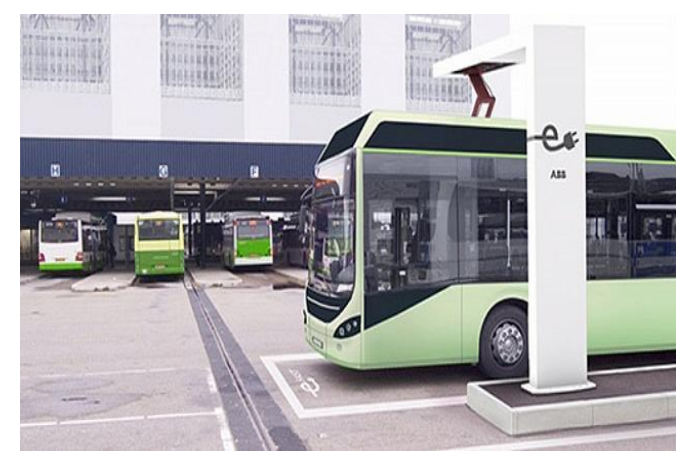

Figure 4. Quick electrobus charge (Luxemburg).

\section{Fuel Cell Electrobus}

Another alternative type of energy for motor vehicles is the fuel cell. A fuel cell intended to replace an ICE consists of a great number of cells (small generators). The voltage of each cell is from 0.6 to $1.0 \mathrm{~V}$. By connecting the cells in series, you can get the required voltage. Modern technology allows making cells up to $1.5 \mathrm{~mm}$ thick. Consequently, it is possible to make the fuel installation of the same mass and dimensions as that of an ICE without loss of power $[8-10,36]$. The main advantage of introducing fuel cells in vehicles is high efficiency. For example, the efficiency of a modern automobile ICE reaches $30 \div$ $35 \%$, and the efficiency of a hydrogen fuel cell is from $45 \%$ to $85 \%$ [37]. The fuel cells on proton-exchange membrane are usually installed on cars and buses. Their main advantages are compactness, low weight, and low process temperature. One of the main disadvantages of fuel installation is its price (about $10 \div 100$ times more expensive than the ICE), as expensive materials and complicated, energy-consuming technologies are used at its manufacture. However, despite this, the European Union has adopted the "Clean Hydrogen in European Cities" programme (CHIC), which provides the use of hybrid buses working on hydrogen on city routes. This program promotes the transition of the bus fleet to hybrid power plants based on hydrogen fuel cells. According to this programme, 26 new buses with hybrid power units have already appeared (in Milan, London, Oslo, Bolzano and Aarau) [38]. The leading European bus manufacturers German Mereceds-Benz, Belgian VanHool and Irish Wright are taking part in the CHIC programme. Hence, the VanHool company uses a hybrid series AG300, developed together with the US companies UTC Power and ISE Corp. The AG300 is equipped with electric motors and fuel cells with the power of $120 \mathrm{~kW}$, which makes possible for the bus to reach a maximum speed of $105 \mathrm{~km} / \mathrm{h}$, and provide a mileage of $400-450 \mathrm{~km}$ when fully filled with hydrogen. Meanwhile, Mereceds-Benz usesan environmentally friendly bus of the second generation - Citaro FuelCell Hybrid (Figure 5) [39]. These buses have a mileage of 200-250 km with a hydrogen reserve of $35 \mathrm{~kg}$.

It should be noted that fuel cells as an energy source for buses excel different types of batteries in many respects, since they have better specific energy indicators. For greater clarity, Figure 6 shows the practical mileage of the vehicle fuelled by fuel cells in comparison with lead-acid, nickel-metal hydride and lithium-ion batteries [40]. As it is 
well-known, the non-linear dependence of the batteries imposes restrictions on their size and weight. Fuel cells have characteristics similar to ICE, and their operation for mileage over long distances will require only additional fuel. However, the fuel cells possess inertness and have a limited power range, which requires the addition of batteries to vehicles. In this regard, the car (bus) on fuel cells resembles an electric car with a builtin charger that maintains the level of the battery's charge.

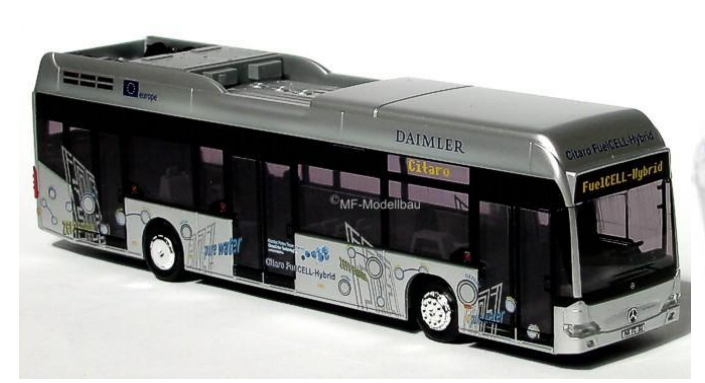

(a)

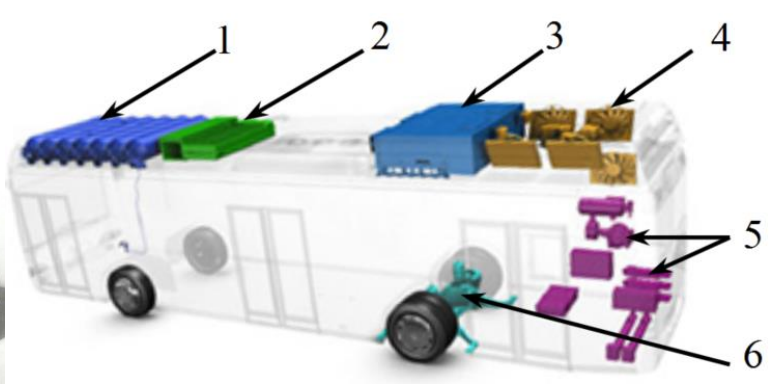

(b)

Figure 5. Electrobus Citaro FuelCell Hybrid (a) outer appearance, (b) electrobus design, (1) $\mathrm{H}_{2}$ Tanks, (2) Battery, (3) FC System, (4) Cooling System, (5) Auxiliary components, and (6) Wheel-hub motor [39].

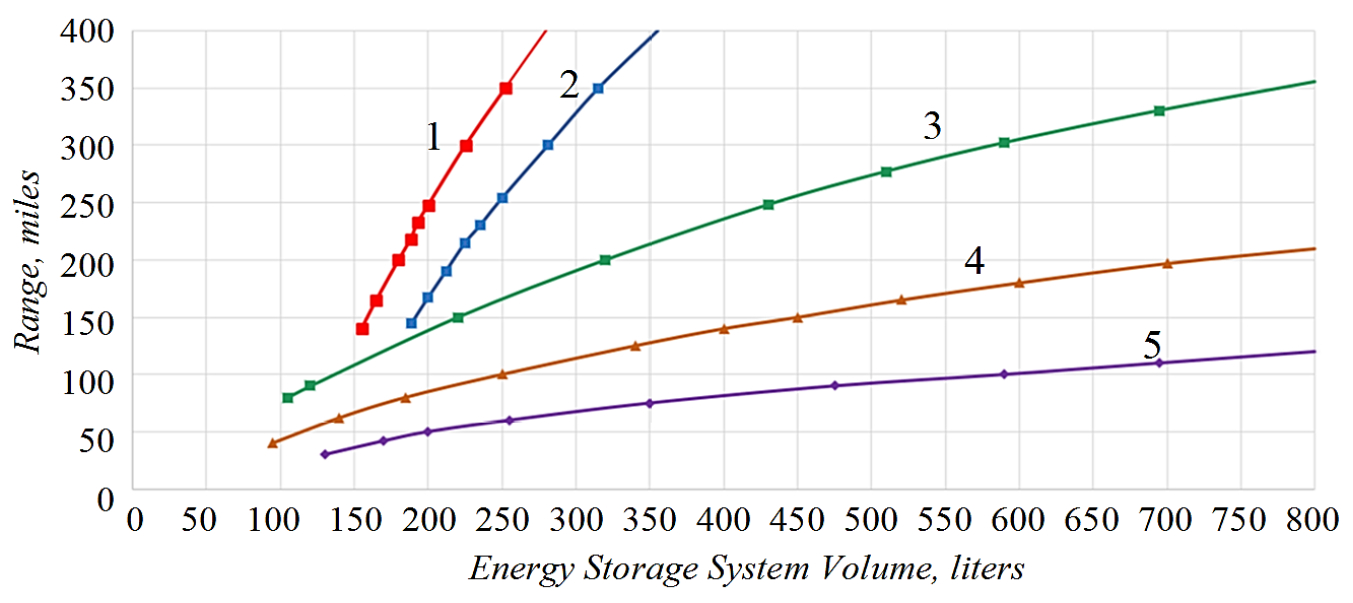

Figure 6. Mileage depending on the way of energy accumulation: (1) $70 \mathrm{MPa}$, (2) Fuel Cell \&Hydrogen Tanks $35 \mathrm{MPa}$, (3) Li-ion Battery,

(4) NiMH Battery, and (5) Pba Battery [40].

In addition to the fact that buses on fuel cells are an environmentally friendly kind of transport, which is undoubtedly their advantage, one should also note their shortcomings [41]. Disadvantages of vehicles on fuel cells

1. A mixture of hydrogen and air is explosive. Hydrogen is more dangerous than gasoline, as it burns mixed with air in a wider range of concentrations.

2. Hydrogen is stored in tanks at high pressure (35 $\mathrm{MPa}$ and $70 \mathrm{MPa})$. For transport, special safe hydrogen storage systems are being developed - the tanks with multi-layered walls made of special materials, etc. All these, in general increase the cost of the entire operation cycle of the vehicle.

3. Hydrogen power plant based on the traditional ICE is much more complicated and expensive to maintain than the conventional ICE (10-100 times). 
4. For refuelling with hydrogen building, a network of special gas stations is required. For filling stations that fill cars with liquid hydrogen, the cost of the equipment is higher than for filling stations that fill cars with liquid fuel (about 10 times).

5. The price is $\$ 8.47$ for 1 litre (which in terms of gasoline equivalent is $\$ 2.86$ per litre.

6. Hydrogen is difficult to keep in liquid form (it has the greatest volatility among gases). For example, in just 9 days, half of the BMW Hydrogen 7 fuel tank evaporates [41].

7. The process of hydrogen production is energy-consuming. The simplest way to produce hydrogen is by electrolysis. However, to generate hydrogen in this way, you need to spend $4 \mathrm{~kW}$ of electricity to produce about $1 \mathrm{~m} 3$ of hydrogen, which, after it burns, will give only $1.8 \mathrm{~kW}[13,14]$.

All these shortcomings predetermine the search for new technologies in the development and implementation of environmentally friendly kinds of transport. Electric vehicles with energy storage devices in the form of ultracapacitors can be classified as one of those.

\section{Ultracapacitor Electrobus}

Ultracapacitor electrobus is a new vehicle which is an intermediate link between ordinary electric transport and trolleybuses. An electrobus is charged from super-fast charging stations during passengers' boarding and disembarking, and is capable of covering the whole route without the necessity of long batteries charging [42]. For example, in a Chinese city Ningbo, Zhejiang province, there is an eco-friendly route of public transport. It is used by an electrobus that obtains relatively small motivity on the stops when the passengers board and disembark (approximately 10 seconds), Figure 7. An interesting new type of an electrobus is the one designed by Zhuzhou Electric Locomotive Company. The company offered to equip public transport with special saddle on the roof for a quick charge. On the stops along the route there are supporting brackets with attaching plugs that are inserted in bus connectors. One such charging provides $5 \mathrm{~km}$ of vehicle usage. It works due to ultracapacitors that are designed to be able to charge million cycles and work for 12 years and it has the working temperatures from -40 до $+65^{\circ} \mathrm{C}$ [42].
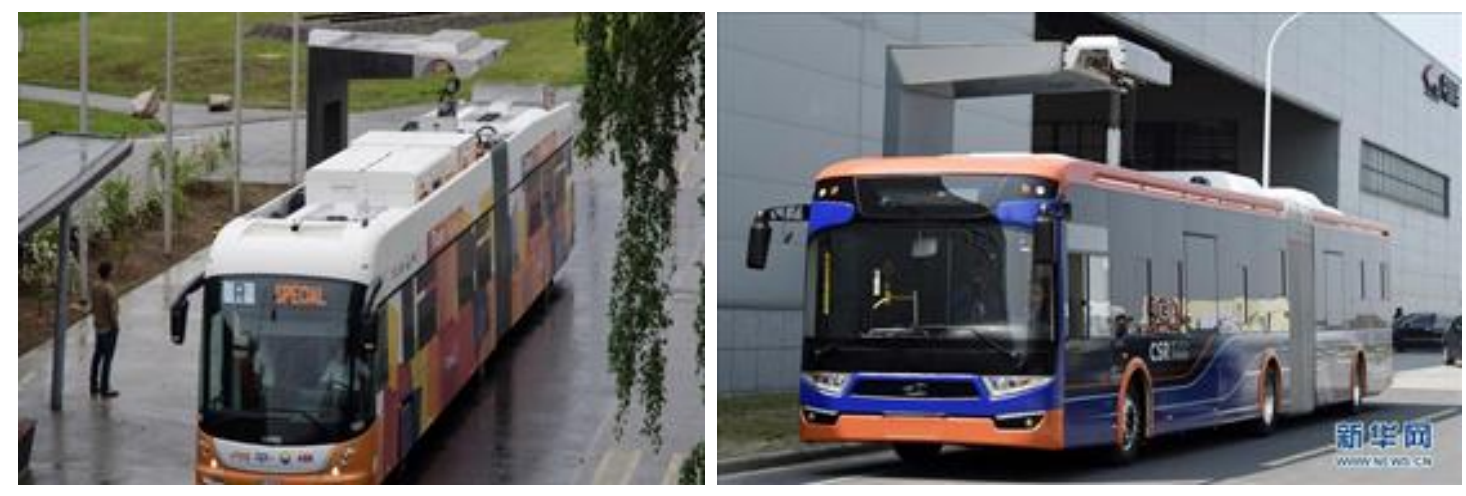

Figure 7. Ultracapacitors electrobuses of China South Locomotive \& Rolling Stock Corporation.

Along with the undeniable advantages of electrobuses on supercapacitors, there are two significant drawbacks: a small mileage on one charge and the need for super- 
powerful, and, therefore, expensive charging stations that could provide a full charge of the super-capacitor block in a few seconds.

\section{Comparison of Different Types of Buses}

To find out which bus will consume less fuel (or electric energy), the comparison of an ordinary diesel bus, a hybrid bus, an electrobus with accumulators and an ultracapacitors bus will be held. We will not consider buses on hydrogen fuel cells as to date their operating costs are several times higher than those of the analogues under consideration. For better data demonstration, one route in Kharkiv (Ukraine) was chosen (12 Kvitnya st. - Horizont residential area, route № 276e). One way ride comprises $4.23 \mathrm{~km}$. The ride time is 10 minutes. The number of stops is 7 (Figure 8). It has to be mentioned, that the goal of these calculations is to report indicative information referring to fuel expenses for different types of buses, which will provide an opportunity to conduct their comparative analysis. A diesel bus "Bogdan" A091 in Kharkiv rides on this route. Fuel consumption is 20-25 litres per $100 \mathrm{~km}$. The bus makes 25-30 of such rides per day. The price of 1 litre of diesel gas oil in Ukraine is $\$ 0.8$ (an average price as of March 2017). The expenses for fuel per day are approximately $\$ 50$. If we choose a hybrid bus, for operation of which not only a diesel but also an electric engine with the capacity of $180 \mathrm{~kW}$ is used, the approximate saving of diesel gas oil will be $40 \%[5,7,29,43,44]$. Thus, the expenses for diesel gas oil for a hybrid bus on the given route will amount to $\$ 30$. About $\$ 10$ for charging energy accumulators have to be added to this, so actually the expenses are $\$ 40$.
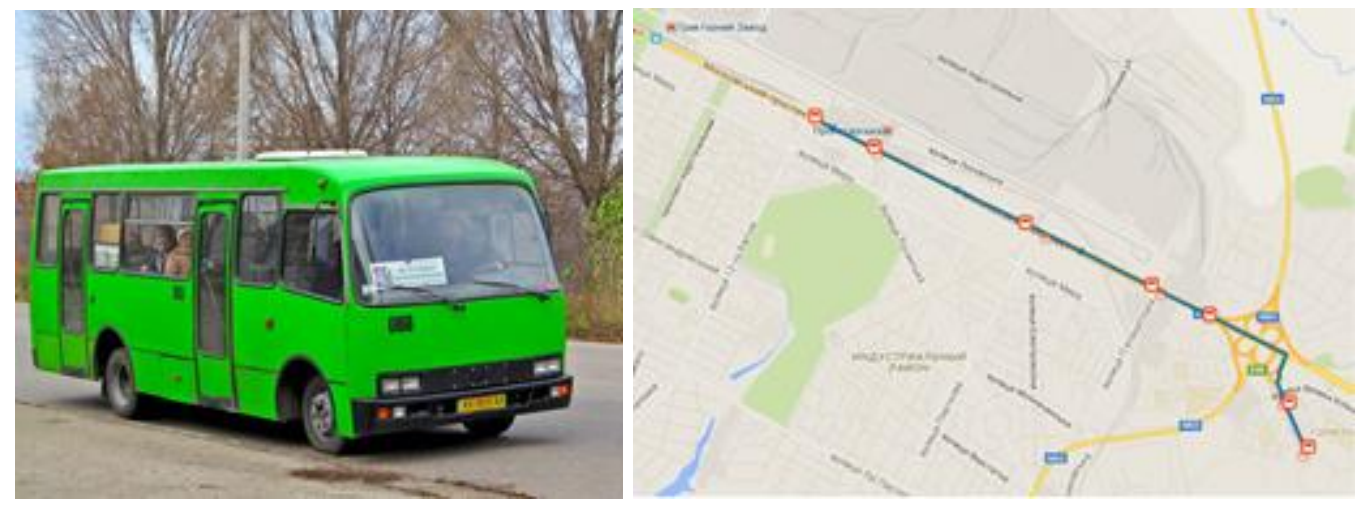

Figure 8. Route № 276e, Kharkiv (Ukraine)

If we consider an electrobus, which is set in motion by an electric engine with the capacity of $230 \mathrm{~kW}$, then the operating costs for one working day will be much smaller. For example, Lviv "Elektron E 19101" bus that can operate without recharging up to 210 $\mathrm{km}$, and needs just 15-20 minutes to be charged by 70\% (such a bus is suitable for this route). Accumulating batteries (Li-Ion) are installed in the "Elektron E 19101" bus with the capacity of $120 \mathrm{~kW}$ per year. Hence, an electrobus will spend $120 \mathrm{~kW}$ in one working day. Thus, approximately $\$ 10$ will be spent for electric energy per day. Therefore, an "Elektron E 19101" electrobus is the most economic one in comparison with other buses but this bus uses ordinary Li-Ion accumulating batteries as energy accumulators. Their service period with such intensive work will be approximately 5 years. It is a serious disadvantage of such electrobuses. In such analysis great attention should also be paid to the cost of Li-Ion accumulators. All these considerably lessen the economic efficiency of electric transport. 
It is offered to choose an electrobus that uses ultracapacitors instead of ordinary accumulators. The service life of ultracapacitors is much longer than Li-Ion accumulators. As it was mentioned before, a typical service period of the accumulator battery of the modern bus is 5 years and a service period of the whole bus is 10-12 years. This means that during the period of service a powerful battery will have to be changed at least once. Ultracapacitors do not require replacement during the whole period of a bus service [45]. In Table 1 comparative characteristics of different energy accumulators are presented.

Table 1. Comparative characteristics of different electric power accumulators.

\begin{tabular}{|c|c|c|c|c|}
\hline Type & & Accumulat & & J lltracanacito \\
\hline Indexes & Acid & Alkaline & Li-ion & apactio \\
\hline Intensity, W·year $/ \mathrm{kg}$ & $20-40$ & $15-80$ & $80-220$ & $2-10$ \\
\hline Maximum unit capacity, W/kg & $100-300$ & $500-1300$ & $800-3000$ & $1500-12000$ \\
\hline Cycle & $100-400$ & $300-2000$ & $500-2500$ & $>1 \mathrm{mln}$ \\
\hline Period of service, years & $2-10$ & $2-15$ & $3-10$ & $>20$ \\
\hline Working temperature, ${ }^{\circ} \mathrm{C}$ & $-30 \ldots 45$ & $-40 \ldots+60$ & $-30 \ldots+60$ & $-50 \ldots+70$ \\
\hline Efficiency, \% & $70-85$ & $65-80$ & $80-95$ & $>90$ \\
\hline Maintenance & \multicolumn{2}{|c|}{ necessary } & no & No \\
\hline Cost, $\$ / \mathrm{kW}$ (indicated power) & $50-120$ & $75-400$ & $400-670$ & $50-100$ \\
\hline
\end{tabular}

The following benefits make condensing type more favourable:

a) The biggest intensity weight and volume capacity;

b) Ability to sustain serious intensity and recharging without getting out of order and operating safety;

c) Low level of self-discharge;

d) Wide range of working temperatures and does not require maintenance when in service;

e) High reliability of units confirmed by many years of bed tests and consumers use.

A great number of charge-discharge cycles are required from an accumulator due to the specific of a city bus work with frequent stops, slow-downing and speeding-up. The number of cycles, depending on the intensity of riding, is 500-1000 per day, and it is over a million cycles for 10 years of use. Thus, ultra-capacitors batteries have better technical and economic indexes than accumulators. Ultra-capacitors are characterised by the longest period of service, the smallest weight, a wider range of working temperatures, and absence of necessity for maintenance. Thus, the analysis which was carried out showed that in terms of operating costs, electrobuses on accumulators are the most economic ones, but their high price and a short period of Li-Ion accumulators use can seriously reduce their attractiveness. Therefore, electrobus with ultracapacitors seems to be quite suitable and prospective for city transportation, as, when produced locally, energy accumulators of such a type will have a smaller prime cost than the Li-Ion accumulators, and the service period will be much longer than the one of the whole bus.

\section{Ultra-capacitors Electrobus Model}

It is offered to make an electrobus on the basis of small class buses, for example, "Bogdan A091", which will have an ultra-capacitors unit (3) with control equipment (Figure 9) where engine is located. Two electric engines (4) were placed directly on the axis of wheels rotation as it is depicted in Figure 9. 


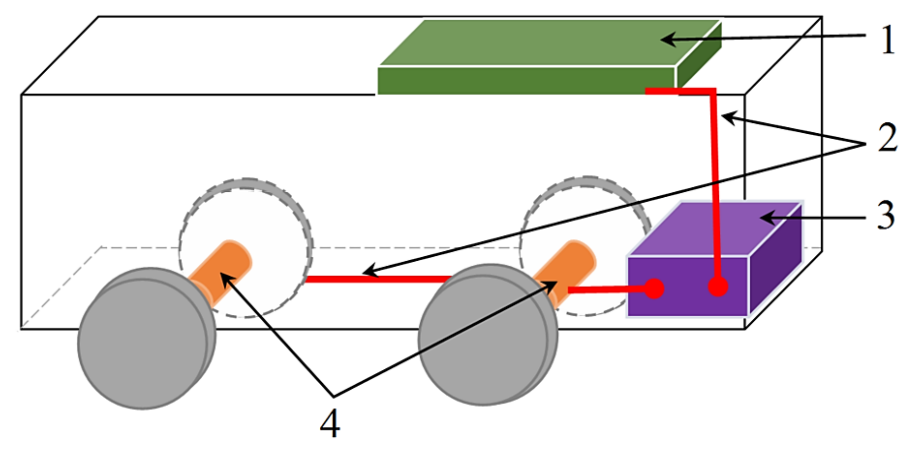

Figure 9. Schematic diagram of an electrocapacitors electrobus (1) charger, (2) lines, (3) ultra-capacitors unit, and (4) electric engines.

Table 2. Technical requirements for "Bogdan A091" electrobus.

\begin{tabular}{lc}
\hline \multicolumn{1}{c}{ Name } & Value \\
\hline Indicated power of an electric engine, $\mathrm{kW}$ & 60 \\
Maximum power of an electric engine, $\mathrm{kW}$ & 120 (two $* 60)$ \\
Indicated power of an accumulator, $\mathrm{kW}$ & 90 \\
Energy of accumulator with indicated power, $\mathrm{mJ}$ & more than 1,44 \\
Cycle & $<1000000$ \\
Efficiency in cycle charge/ discharge $(\eta)$ & $<0,8$ \\
Period of service, years & 10 \\
Maximum operational km by means of energy accumulator, $\mathrm{km}$ & Up to 5 \\
\hline
\end{tabular}

Table 3. Accumulator on the basis of Ultracapacitors EC for electric drive of a "Bogdan A091" city bus.

\begin{tabular}{|c|c|}
\hline Name & Value \\
\hline Accumulator model & $14 \times 30 Э К 404$ \\
\hline Intensity, W & 630 \\
\hline Capacity, F & 28,6 \\
\hline Volume, 1 & 420 \\
\hline Weight, kg & 520 \\
\hline Indicated power, $\mathrm{kW}$ & 90 \\
\hline Efficiency in cycle charge/ discharge $(\eta)$ & $>0,8$ \\
\hline Condenser module & З0ЭК404 \\
\hline Intensity, W & 45 \\
\hline Capacity, F & 400 \\
\hline Internal resistance, $\mathrm{mOhm}$ & 12 \\
\hline Weight, kg & 37 \\
\hline Overall dimensions, $\mathrm{mm}$ & $560 \times 219 \times 245$ \\
\hline Working temperature, ${ }^{\circ} \mathrm{C}$ & $-50 \ldots+70$ \\
\hline
\end{tabular}

A charger was located on the roof of an electrobus, which allowed charging ultracapacitors safely on public transport stops. The choice of a certain type of an electronic machine for an electrobus cannot be made separately from the choice of other elements of an electric traction drive. The use of every type of engines requires considerable 
changes of a power converter, mechanic elements (gear system, brakes), a set of primary indicators (location sensors, speed etc.), and also defines the control system construction. According to the calculations, the technical requirements for the components of an electric motor unit as a part of "Bogdan A091" city bus can be defined as follows (Tables 2-4). The calculated time of ultra-capacitor charging will be from 20-30 sec to $5 \mathrm{~min}$. This time is defined by a charger capacity. Arranging chargers according to the scheme offered by ABB Company is suggested, as it meets all the standards, safety protocols and norms that are required for public transport in EU countries.

Table 4 Characteristics of a city bus "Bogdan A091" with electrodrive

\begin{tabular}{|c|c|}
\hline Name & Value \\
\hline Length, $\mathrm{m}$ & 7,2 \\
\hline Full weight, $\mathrm{t}$ & 8 \\
\hline Passenger capacity, $\mathrm{p}$. & 45 \\
\hline Indicated power of a traction electric motor, $\mathrm{kW}$ & 60 \\
\hline Overall volume, 1 & 420 \\
\hline Weight, kg & 520 \\
\hline Maximum speed, $\mathrm{km} / \mathrm{h}$ & 70 \\
\hline Acceleration time up to $50 \mathrm{~km} / \mathrm{h}, \mathrm{s}$ & 25 \\
\hline Average efficiency of recuperation & 0,23 \\
\hline Average specific power consumption, $\mathrm{W} \cdot \mathrm{h} /(\mathrm{t} \cdot \mathrm{km})$ & $80-84$ \\
\hline Maximum operational $\mathrm{km}$ by means of energy accumulator, $\mathrm{km}$ & up to 5 \\
\hline
\end{tabular}

\section{RESULTS AND DISCUSSION}

One of the important steps in improving the environment (especially in cities with a large number of road transport) is the replacement of ICE cars with an environmentally friendly type of vehicles. Concerning private car owners, the replacement of ICE cars with electric vehicles or hybrid cars is supported by various programmes at the state level and is quite fast and efficient. Motorists gradually transfer to environmentally friendly cars. However, we should not forget about urban transport, in particular, buses. It is a very convenient and popular means of transport, which helps millions of passengers daily to travel not only within the city or country but also beyond the borders. Therefore, the problem of environmental pollution with exhaust gases from diesel buses is acute. Before replacing bus fleets or converting them into modern ecological buses, all possible pros and cons should be learned and evaluated (when they are implemented). As for electric fuel buses, their main advantages are environmental safety and high efficiency [37]. In the European Union, the Clean Hydrogen in European Cities programme was adopted, which envisages the use of hybrid buses operating on hydrogen fuel for urban transport [38, 39]. Nevertheless, we should not forget about the significant disadvantages of this type of transport, namely a mixture of hydrogen and air is explosive, special tanks are needed for storing and transporting hydrogen that ensure high pressure (35 $\mathrm{MPa}$ and $70 \mathrm{MPa}$ ), they are more difficult and expensive (10-100 times than ICE) in maintenance, a network of special filling stations is needed for filling with hydrogen, hydrogen is difficult to keep in liquid form (it has the highest volatility among gases), and the process of hydrogen production is energy-consuming $[13,14]$. Considering the enumerated shortcomings, electrobuses and hybrid buses look like more promising. 
Hybrid buses let maximally reduce fuel consumption, which leads to the minimum emissions release to the atmosphere [5, 29-31, 46]. Hybrid power plant in the bus allows saving up to $60 \%$ of energy as compared to diesel units, fuel consumption reduces up to $30 \%$, and harmful emissions into the atmosphere diminish by $70 \%$. To date, hybrid vehicles have one significant advantage over electric vehicles - they are more autonomous due to the presence of ICE. However, in other respects the leading position is occupied by electric transport. It is especially true for electrobuses serving short routes within the city limits. The successful use of electrobuses for transportation in the city in developed countries proves that $[33,34]$. The biggest representative of electrobuses is BYD Auto Company with a K9 model (China). These electrobuses are able to overcome the distance of $250 \ldots 300 \mathrm{~km}$ in the city without recharging. The time of their charging in special terminals is 3 hours [33]. ABB company in Luxemburg has launched rapid charge automatic systems with automatic linking-up on the roof, which can clear away one of the main obstacles for the expansion of city electrobuses use - a long time of charge with short rolling distances [35]. A common drawback of the electrobuses, is their high cost (mainly due to expensive batteries), as well as the complexity and high cost of equipment for their fast charge. Another factor is perhaps the most modern type of ecological bus is the electrobus on supercapacitors. Its difference from a conventional electrobus is the ultra-high-speed charging of supercapacitors from high-speed chargers installed at stops. Charging is accomplished very quickly - during the passengers boarding/disembarking. An example of such electrobus is the product of the Zhuzhou Electric Locomotive Company [46], which has proposed to equip public transport with special nests on the roof for quick recharging. The charging stations are established at stops along the route. One such recharging provides a run up to $5 \mathrm{~km}$. It works well due to ultracapacitors designed for a million cycles of recharging, which is about 12-15 years of service, while operating temperatures are from $-40^{\circ}$ to $+65^{\circ} \mathrm{C}$ [42]. As was mentioned earlier, along with the undeniable advantages of these electrobuses on supercapacitors, there are two significant drawbacks: a small mileage on one charge and the need for super-powerful, and, therefore, expensive charging stations that could provide a full charge of supercapacitors in a few seconds.

Each of the ecological buses considered above has its advantages and disadvantages. Therefore, the decision to use them depends on many factors: mileage without recharging, weight and size indicators, and of course, an economic factor. At the moment, the Ukrainian motor-transport industry is at the initial stage of developing environmental means of transport. On the one hand, it is a problem but on the other hand, it is possible to choose the most suitable development strategy for this industry right now and gradually arrange the infrastructure (depending on the chosen direction) to transfer drivers and passengers to more economical and environmentally friendly transport. Of course, new buses offered by the leading manufacturers of modern kinds of transport should be purchased. However, such buses are very expensive thus replacing the entire fleet will take years or even decades. The proposed way of re-equipment of Bogdan A091 diesel buses into electrobuses is ten times cheaper, and therefore, more affordable for Ukrainian motor-transport enterprises. The calculated time of ultra-capacitor charging will be from 20-30 sec to $5 \mathrm{~min}$. The time is determined by a charger capacity. In Europe, ABB has already developed and offered high-speed chargers for bus transport [35]. As they are designed in accordance with all necessary for this industry standards and safety requirements, they can be used as charging systems. The implementation of the programme for buses conversion cannot be accomplished without the state subsidies and investments. It should be borne in mind that flawless operation of the electrobuses can be 
ensured only by installing a sufficient number of chargers. However, in the result of the state, the private owners of motor transport enterprises, and, of course, the passengers will win. At the present stage, the results of comparison of different possible decisions on conversion of the urban bus with ICE into an energy saving and environmentally friendly electric bus have an evaluation (indicative) nature. The calculation of technical characteristics of an electric bus with ultra-capacitors can be considered as a basis for further research in this area. Such research can involve simulation of the processes in the electric bus while driving, prototyped experimental studies of its individual structural, and design elements as well as experiments on real objects.

\section{CONCLUSIONS}

A decrease in supplies of non-renewable energy sources, as well as the ecological state of big cities forces the authority to seek the best solutions for introducing energy-efficient, environmentally-friendly technologies for the urban bus transport. The review of the main types of environmentally friendly buses has been made. This review showed that electric buses are the most universal, environmentally friendly, and economical means of transport. However, fast replacement of the whole bus fleet with new electric buses is impossible because of their high cost. That is why in order to choose the optimal variant acceptable particularly for urban operating conditions a comparative analysis of operating costs for buses of different types but of the same class was carried out. For this, a particular one way route in Kharkiv (Ukraine) with the length of $4.23 \mathrm{~km}$ was chosen. Experimental and calculated data showed that the use of a minibus converted into an electric bus is the most acceptable way for intra-urban passenger transportation. It is proposed to use ultra-capacitors as a source of energy. The calculated time of ultracapacitors charging will be from 20-30 sec to $5 \mathrm{~min}$. This time is defined by a charger capacity. Arranging chargers according to the scheme offered by ABB Company is suggested, as it meets all the standards, safety protocols, and norms that are required for public transport in EU countries. A schematic diagram of the model of such an electric bus is presented and the technical requirements for its components are determined. These developments and proposals are useful for application both in Ukraine and in countries with low economic development that do not allow quick replacement of old diesel buses for the new environmentally friendly electric buses. The results of this work are of an evaluation nature and can be considered as a justification for further studies in the field of energy-efficient technologies for urban bus transport. Such studies may include simulation of processes in the electric bus while driving, prototyped experimental studies of its individual structural and design elements, and experiments on real objects.

\section{ACKNOWLEDGEMENTS}

This work was conducted under the Scientific research "Development of the system of energy saving and electric energy generation for vehicles", 04-53-17, funded by the Ministry of Education and Science of Ukraine.

\section{REFERENCES}

[1] Psyk V, Risch D, Kinsey BL, Tekkaya A, Kleiner M. Electromagnetic forminga review. Journal of Materials Processing Technology. 2011;211:787-829. 
[2] Gnatov A, Argun S. New method of car body panel external straightening: tools of method. International journal of vehicular technology. 2015;2015:1-7.

[3] Momang W, Mohamed NMZN. Development concept of a portable qualityconfirmation inspection device for automotive body parts. International Journal of Automotive and Mechanical Engineering. 2015;11:2738-46.

[4] McLauchlan PA, Stephens B. Global climate change-air and sea pollutant emissions from shipping: A global problem with global (and local) solutions. Journal of Transportation Law, Logistics, and Policy. 2016;83:201-16.

[5] Brand C. Beyond 'Dieselgate': Implications of unaccounted and future air pollutant emissions and energy use for cars in the United Kingdom. Energy Policy. 2016;97:1-12.

[6] Yuan X, Ma R, Zuo J, Mu R. Towards a sustainable society: the status and future of energy performance contracting in China. Journal of Cleaner Production. 2016;112:1608-18.

[7] Nayak SK, Mishra PC. Emission from a dual fuel operated diesel engine fuelled with Calophyllum Inophyllum biodiesel and producer gas. International Journal of Automotive and Mechanical Engineering. 2017;14:3954-69.

[8] Yupeng L, Jin L, Zirui Q, Zongtian W. Development of fuel cell hybrid electric city bus. IEEE Conference and Expo on Transportation Electrification AsiaPacific (ITEC Asia-Pacific): IEEE; 2014. p. 1-6.

[9] Bartłomiejczyk M, Jarzębowicz L. Energy savings by application of supercapacitor storage in trolleybus supplying station--analysis of experimental results. Technical Transactions. 2016;2:17-32.

[10] Holdcroft S, Britton B, Skalski T. High performance, high catalyst-efficiency hydrocarbon fuel cells. Meeting Abstracts: The Electrochemical Society; 2016. p. 2607.

[11] D'Ovidio G, Masciovecchio C, Rotondale A. Hydrogen fuel cell and kinetic energy recover systems technologies for powering urban bus with zero emission energy cycle. IET Intelligent Transport Systems. 2016;10:573-8.

[12] Carnevali C, Genova R, Jenné P, Mazzuchelli M, Reijalt M, Priano G. Fuel cell electric buses and perspectives: High V. LO-city project authors. IEEE International Energy Conference and Exhibition (ENERGYCON): IEEE; 2012. p. 1039-43.

[13] Bolvashenkov I, Herzog H-G. Highly effective hydrogen production process based on Tolman-Stewart effect: Feasibility of its implementation. IEEE 8th International Conference and Exhibition on Ecological Vehicles and Renewable Energies 2013. p. 1-4.

[14] Dahbi S, Aboutni R, Aziz A, Benazzi N, Elhafyani M, Kassmi K. Optimised hydrogen production by a photovoltaic-electrolysis system DC/DC converter and water flow controller. International Journal of Hydrogen Energy. 2016;41:2085866.

[15] Wu X, Hu C, Chen J. Energy flow chart-based energy efficiency analysis of a range-extended electric bus. Mathematical Problems in Engineering. 2014;2014:1-12.

[16] Xu L, Yang F, Hu M, Li J, Ouyang M. Comparison of energy management strategies for a range extended electric city bus. IEEE st Chinese Control Conference 2012. p. 6866-71. 
[17] Ye X, Jin Z, Hu X, Li Y, Lu Q. Modeling and control strategy development of a parallel hybrid electric bus. International journal of automotive technology. 2013;14:971-85.

[18] Mohd TAT, Hassan MK, A. Aziz WMK. Mathematical modeling and simulation of an electric vehicle. Journal of Mechanical Engineering and Sciences. 2015;8:1312-21.

[19] Zhang X, Xie J, Rao R, Liang Y. Policy incentives for the adoption of electric vehicles across countries. Sustainability. 2014;6:8056-78.

[20] Trigg T, Telleen P, Boyd R, Cuenot F, D'Ambrosio D, Gaghen R, et al. Global EV outlook: understanding the electric vehicle landscape to 2020. Int Energy Agency. 2013:1-40.

[21] Wahono B, Nur A, Santoso WB, Praptijanto A. A comparison study of rangeextended engines for electric vehicle based on vehicle simulator. Journal of Mechanical Engineering and Sciences. 2016;10:1803-16.

[22] Yilmaz M, Krein PT. Review of battery charger topologies, charging power levels, and infrastructure for plug-in electric and hybrid vehicles. IEEE transactions on Power Electronics. 2013;28:2151-69.

[23] Zulkifli SA, Mohd S, Saad N, Aziz ARA. Operation and control of split-parallel, through-the-road hybrid electric vehicle with in-wheel motors. International Journal of Automotive and Mechanical Engineering. 2015;11:2793-808.

[24] Liu Z, Wen F, Ledwich G. Optimal planning of electric-vehicle charging stations in distribution systems. IEEE Transactions on Power Delivery. 2013;28:102-10.

[25] Hatton C, Beella S, Brezet J, Wijnia Y. Charging Stations for Urban Settings the design of a product platform for electric vehicle infrastructure in Dutch cities. World Electric Vehicle Journal. 2009;3:1-13.

[26] Wirges J, Linder S, Kessler A. Modelling the development of a regional charging infrastructure for electric vehicles in time and space. European Journal of Transport and Infrastructure Research. 2012;12:391-416.

[27] Гнатов А, Аргун Щ, Ульянец О. Енергозберігаючі технології на транспорті. Наукові нотатки. 2016:80-6.

[28] Salisa AR, Walker PD, Zhang N, Zhu JG. Comparative cost-based analysis of a novel plug-in hybrid electric vehicle with conventional and hybrid electric vehicles. International Journal of Automotive and Mechanical Engineering. 2015;11:2262-71.

[29] Chen Y, Li J, Zhang S. Design and analysis of plug-in hybrid electric school bus. International Journal of Vehicle Design. 2015;69:273-84.

[30] Halmeaho T, Rahkola P, Pippuri J, Tammi K. Hybrid city bus design evaluation using system level simulations. IEEE 23rd International Symposium on Industrial Electronics 2014. p. 1671-6.

[31] Jobson E. Volvo 7700 Hybrid, The worlds most environmentally friendly bus. Volvo Bus Corporation. 2010.

[32] Channapattana S, Pawar AA, Kamble PG. Effect of injection pressure on the performance and emission characteristics of VCR engine using honne biodiesel as a fuel. Materials Today: Proceedings. 2015;2:1316-25.

[33] Lajunen A. Powertrain design alternatives for electric city bus. IEEE Vehicle Power and Propulsion Conference 2012. p. 1112-7.

[34] Wang H, Kimble C. Innovation and leapfrogging in the chinese automobile industry: Examples from Geely, BYD, and Shifeng. Global Business and Organizational Excellence. 2013;32:6-17. 
[35] Гнатов А, Аргун Щ, Быкова E, Пидгора А. Электробус на суперконденсаторах для городских перевозок. Вестник Харьковского национального автомобильно-дорожного университета. 2016;72:29-34.

[36] Garcia P, Fernandez LM, Garcia CA, Jurado F. Fuel cell-battery hybrid system for transport applications. IEEE International Conference on Electrical Machines and Systems2009. p. 1-5.

[37] San Marchi C, Hecht E, Ekoto I, Groth K, LaFleur C, Somerday B, et al. Overview of the DOE hydrogen safety, codes and standards program, part 3: Advances in research and development to enhance the scientific basis for hydrogen regulations, codes and standards. International Journal of Hydrogen Energy. 2017;42:726374.

[38] Vierling D, Dworacek J, Zid HB, Schmuelling B. Smart trolley-bus systems: Why a presumed dead relic makes the difference to re-electrify public transportation. IEEE International Energy Conference (ENERGYCON)2016. p. 1-6.

[39] Alazemi J. Automotive solar hydrogen fuelling stations: Concept design, performance testing and evaluation. 2016.

[40] Чудотворова Е, Бестужев П, Козляков В. Алюмоводородные технологии в экологии и на транспорте. 2016.

[41] Nakayama J, Sakamoto J, Kasai N, Shibutani T, Miyake A. Preliminary hazard identification for qualitative risk assessment on a hybrid gasoline-hydrogen fueling station with an on-site hydrogen production system using organic chemical hydride. International Journal of Hydrogen Energy. 2016;41:7518-25.

[42] The world's fastest charging electric bus powers up in 10 seconds flat. https://inhabitat.com/the-worlds-fastest-charging-electric-bus-powers-up-in-10seconds-flat/2016.

[43] Hasan MM, Rahman MM, Kadirgama K. A review on homogeneous charge compression ignition engine performance using biodiesel-diesel blend as a fuel. International Journal of Automotive and Mechanical Engineering. 2015;11:2199211.

[44] Salisa A, Walker P, Zhang N, Zhu J. Comparative cost-based analysis of a novel plug-in hybrid electric vehicle with conventional and hybrid electric vehicles. International Journal of Automotive and Mechanical Engineering. 2015;11:2262.

[45] Гаврилюк Е, Манцеров С, Синичкин С. Методика оценки технического состояния систем автоматического управления газоперекачивающими агрегатами. Труды Нижегородского государственного технического университета им РЕ Алексеева-Нижний Новгород: НГТУ. 2014:107.

[46] Nayak S, Mishra P. Emission from a dual fuel operated diesel engine fuelled with Calophyllum Inophyllum biodiesel and producer gas. International Journal of Automotive \& Mechanical Engineering. 2017;14. 